\title{
IMPROVING THE PROPERTIES OF MEAT ADDITIVES PRODUCED FROM DIFFERENT SOY BEAN BLENDS BY THE SINGLE SCREW EXTRUDER
}

\author{
$\operatorname{Morcos}$ M. A. ", B. M. A. Amer ${ }^{*}$, H. K. El-Manawaty ${ }^{* *}$ \\ and M. M. H. Zakzouk ${ }^{* *}$
}

\begin{abstract}
Processing parameters for improving meat additives produced from soy bean blends were applied including the use of blends of soy bean - faba bean of different ratio (33.3:66.6, 50:50, 66.6:33.3, and 75:25\%) and different moisture contents of $(15,20,25$, and 30\%). Operation parameters of extruder were also applied as barrel temperature without appling any thermal insulation at its three zone (feeding, kneading, and cooking) $\left(90,140,170^{\circ} \mathrm{C}\right)$ and barrel temperature at its three zone after providing thermal insulation for its barrel $\left(95,145,175^{\circ} \mathrm{C}\right)$ and different dies with three diameters $(6,8$, and $10 \mathrm{~mm})$ and three lengths of die (45, 65 , and $85 \mathrm{~mm}$ ). Those applied parameters were provided for evaluating their effect on the chemical and engineering properties of the produced texturized from (soy bean-faba bean) blends. The properties of the produced texturized additives from (soy bean-faba bean) at 50:50\% at moisture content $20 \%$ accompanied by providing thermal insulation for the barrel housing and die's diameter 6mm and its length $85 \mathrm{~mm}$ were the best.
\end{abstract}

\section{INTRODUCTION}

oday, the extruder became one of the most important machines in
food processing, since it is used for making pasta, breakfast
cereals, baby food, snacks food, confectionery items, pet food, extraction of oil and texturized protein (Linko et al. , 1983).

Soybean came the first of the natural alternates for meat, because it is high in protein "containing 38\%" by weight and oil makeing up about $18 \%$ of the weight of soybean seeds (U.S.B, 2004).

\footnotetext{
* Ag. Eng. Dept., Faculty of Agriculture, Cairo University.

**Food Eng. Dept., Food Technology Research Institute, Agricultural Research Center.
} 
The locally produced texturized soybean is containing $7 \%$ fat but the imported one is containing $0.5 \%$ fat; because in abroad it is acceptable to remove the fat by solvent, but the solvent is unacceptable in Egypt since it is: (1) expensive , (2) it's residual affect the quality of the product, and (3) it changes the chemical component of the product.

To reduce the effect of fat, a suggestion of the addition of some legumes which contain low amount of fat was proposed to make soy flour blends having low fat content, since the high content of fat has the effects:

1. Decreasing the coefficient of viscosity which will be reflected in decreasing the internal friction between the raw material and the material of the machine.

2. Increasing the fat ratio in the final product which will be reflected in decreasing in water absorption capacity and this will affect the quality of the final product.

The nutritional value of bean "faba-bean" has been traditionally attributed to it high protein content, which ranges from 25 to 35\%, despite the imbalance in sulphur aminoacids. Most of these proteins are globulins (60\%), albumins (20\%), glutelins (15\%) and prolamins. It is also a good source of sugars, minerals and vitamins. The chemical analysis of this legume reveals a 50-60\% content of carbohydrate, which is mainly constituted by starch, while the proportion of lipids is relatively low at about $1-2.5 \%$ with oleic and linoleic acids representing about $75 \%$ of fats (Larralde and Martinez, 1991).

Liang et al., (2009) mentioned that water absorption capacity for meat additives produced by the extruder increased with feed moisture, barrel temperature, and screw speed. Each of these also contributed to the higher expansion ratio and the lower bulk density. Higher expansion ratio means higher porosity of the sample and hence greater ease for rehydration. All these conditions are indicative of higher and more rapid expulsion of moisture due to the larger pressure difference and higher temperature at the die.

Chakraborty and Banerjee (2009) found that the effect on the expansion ratio by changing die temperature and feed moisture, were significant in 
the first order effect of feed moisture, and second order effect of feed moisture and temperature. Increasing feed moisture and temperature, expansion ratio increased at $15 \%$ moisture content and $181.5^{\circ} \mathrm{C}$ die head temperature and decreased subsequently with the rise in temperature and moisture content. On increasing temperature, gelatinization of starch was more and raised expansion ratio, and with further increase of temperature, starch fragmentation occurred and reduced expansion ratio. Longitudinal expansion and elasticity factors were related with expansion ratio.

This research has been undertaken to study the effect of decreasing heat lose in single screw extruder to improve the properties of extrudates produced from different flour blends at soy bean: faba bean ratios.

\section{MATERIALS AND METHODS}

A single screw extruder was used in this study to produce the locally texturized soybean. The performance of the extruder depends upon both the high pressure imposed by the extruder on soybean flour and the increase of the generated temperature by the frication between extruder inside surfaces and soybean flour. The temperature of the processed material inside the extruder during the process was found to be $140^{\circ} \mathrm{C}$. The extruder drive is a 50HP electric motor. Speed reduction and torque transfer are accomplished through the use of belts. The feeding device of the extruder is a one HP side mounted motor. The fed material is pumped by the screw of the feeding device into the extruder barrel which is also accompanied with a mixing shaft. The extruder barrel assembly consists of a stationary barrel housing, a rotating screw and steamlocks, and die. The extruder barrel housing has inside axial groove design, to insure the slip of the fed material. The extruder's screw geometry influences mixing, kneading, and cooking of the fed material by the developed heat and pressure. The movement and transformation of the fed material within the extruder can be categorized into three zones or sections: feeding, kneading, and final cooking zone. The design of the extruder's screw includes three pieces or parts, each has constant pitch, constant depth, and constant root diameter, and the number of flight on any part is the same in the three zones. Four steamlocks are fixed with the three screw parts to 
limit the beginning and the end of each zone. In previous work the specifications of each of the three screw parts were developed and these three parts were fabricated. The specifications of the extruder's screw are listed in Table (1), (Morcos et al., 2007). A die plate serves as a restriction device at the end of the barrel which can control barrel fill, pressure, and temperature. The "die area" is the section of the extruder that occurs after the material leaves the screw. The applied die hole diameter is $0.8 \mathrm{~cm}$.

Table (1): The specifications of the developed screw and that of the barrel of the applied extruder.

\begin{tabular}{lccc}
\hline \multicolumn{1}{c}{ Dimensions } & Feeding zone & Kneading zone & $\begin{array}{c}\text { Cooking } \\
\text { Zone }\end{array}$ \\
\hline Pitch $(\mathbf{c m})$ & 3.55 & 2.6 & 1.75 \\
Inside diameter $(\mathbf{c m})$ & 7.1 & 7.4 & 7.7 \\
Outside diameter $(\mathbf{c m})$ & 9.2 & 9.2 & 9.2 \\
Piece length $(\mathbf{c m})$ & 12.74 & 12.74 & 12.74 \\
Inside obtained temperature & 90 & 140 & 170 \\
$\left({ }^{\circ} \mathbf{C}\right)$ & & & \\
Steamlocks thickness $(\mathbf{c m})$ & 1.905 & 1.905 & 1.905 \\
Inlet steamlock diameter $(\mathbf{c m})$ & 8.225 & 8.575 & 9.207 \\
Outlet steamlock diameter $(\mathbf{c m})$ & 8.575 & 9.207 & 9.525 \\
\hline
\end{tabular}

Table (2): The specification of barrel housing and isulated materials.

\begin{tabular}{|c|c|c|c|c|}
\hline Description & Unite & $\begin{array}{l}\text { Feeding } \\
\text { zone }\end{array}$ & $\begin{array}{l}\text { Kneading } \\
\text { zone }\end{array}$ & $\begin{array}{l}\text { Cooking } \\
\text { zone }\end{array}$ \\
\hline Length of zone, $L$ & $\mathrm{~m}$ & 0.1263 & 0.1263 & 0.1263 \\
\hline Outer diameter, $\mathrm{D}_{1}$ & $\mathrm{~m}$ & 0.133 & 0.133 & 0.133 \\
\hline Inner diameter, $\mathbf{D}_{2}$ & $\mathrm{~m}$ & 0.10812 & 0.10812 & 0.10812 \\
\hline Ambient temperature, $\mathbf{T}_{3}$ & ${ }^{\circ} \mathrm{C}$ & 25 & 25 & 25 \\
\hline Wall temperature, $\mathbf{T}_{2}$ & ${ }^{\circ} \mathrm{C}$ & 98 & 136 & 164 \\
\hline Soybean temperature, $T_{1}$ & ${ }^{\circ} \mathrm{C}$ & 90 & 140 & 170 \\
\hline Material of insulation & & Glass wool & Glass wool & Glass wool \\
\hline $\begin{array}{l}\text { Thermal conductivety of } \\
\text { barrel material, } k_{B}\end{array}$ & $\mathrm{~W} / \mathrm{m}^{\circ} \mathrm{C}$ & 54 & 54 & 54 \\
\hline $\begin{array}{l}\text { Thermal conductivety of } \\
\text { insulation material, } k_{\text {in }}\end{array}$ & $\mathrm{W} / \mathrm{m}^{\circ} \mathrm{C}$ & 0.038 & 0.038 & 0.038 \\
\hline $\begin{array}{l}\text { Thermal conductivety of } \\
\text { soybean, } k_{s}\end{array}$ & $\mathrm{~W} / \mathrm{m}^{\circ} \mathrm{C}$ & 0.3331 & 0.3331 & 0.3331 \\
\hline $\begin{array}{l}\text { Convection heat transfer } \\
\text { coefficient, } h_{1}\end{array}$ & $\mathrm{~W} / \mathrm{m}^{2 \circ} \mathrm{C}$ & 1843.5 & 1843.5 & 1843.5 \\
\hline
\end{tabular}




\section{The modification of the barrel housing of the single screw extruder}

An insulation in the form of a cylindrical tube was added around the barrel housing. The insulation has two different effects. The additional insulation decrease the rate of the conduction heat transfer of the insulation layer but increases the convection rate of heat transfer of the surface because of the increase in the outer surface area for convection. The heat transfer from the pipe may increase or decrease, depending on which effect dominates.

Considering an insulation cylindrical pipe of outer radius $\mathbf{r}_{3}$ whose outer surface temperature $\mathbf{T}_{\mathbf{3}}$ is maintained constant, Fig (1). The barrel is now insulated by a tube of an insulating material with thermal conductivity of $\mathbf{k}_{\text {in. }}$. Heat is lost from the outer surface of the insulating tube to the surrounding medium at temperature $\mathbf{T}_{\mathbf{3}}$, with convection heat transfer coefficient $\mathbf{h}_{3}$. The rate of heat transfer from the outer surface of the insulated tube to the surrounding air can be expressed as (Kumar, 2012):

$$
Q=\frac{T_{3}-T_{1}}{\frac{1}{\left(2 \pi r_{1} L\right) h_{1}}+\frac{\ln \frac{r_{2}}{r_{1}}}{2 \pi L k_{b}}+\frac{\ln \frac{r_{3}}{r_{2}}}{2 \pi L k_{\text {in }}}+\frac{1}{\left(2 \pi r_{3} L\right) h_{3}}}
$$

Where:

$\mathbf{T}_{1}$ : inner surface temperature of barrel, ${ }^{\circ} \mathrm{C}$

$\mathbf{T}_{2}$ : outer surface temperature of barrel, ${ }^{\circ} \mathrm{C}$

$\mathbf{T}_{3}$ : surrounding medium at temperature, ${ }^{\circ} \mathrm{C}$

$\mathbf{r} 1$ : inner radius of barrel housing, $\mathrm{m}$

$\mathbf{r} 2$ : outer radius of barrel housing, $\mathrm{m}$

$\mathbf{r} 3$ : outer radius of insulated barrel housing, $\mathrm{m}$

$\mathbf{L}$ : length or barrel housing, $\mathrm{m}$

$\mathbf{K}_{\text {in }}$ : thermal conductivity of insulation, $\mathrm{W} / \mathrm{m}^{\circ} \mathrm{C}$

$\mathbf{K}_{\mathbf{B}}$ : thermal conductivity of barrel, $\mathrm{W} / \mathrm{m}^{\circ} \mathrm{C}$

$\mathbf{h}_{1}$ : convection heat transfer coefficient at barell, $\mathrm{W} / \mathrm{m}^{2 \circ} \mathrm{C}$

h3: convection heat transfer coefficient to the surrounding, $\mathrm{W} / \mathrm{m}^{2 \circ} \mathrm{C}$ 


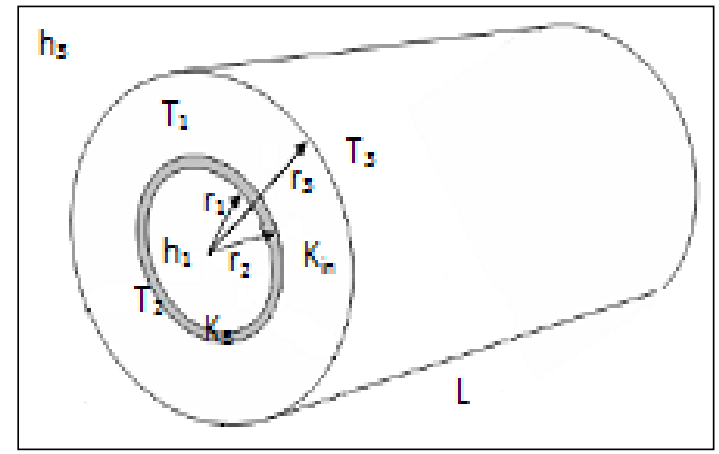

Fig .1. The insulation cylindrical pipe surrounding the extruder barrel.

Heat transfer coefficient of the soybean can be calculated by, (Heldman and Lund, 2007, Lienhard, 2008, Cengel and Ghajar, 2011) and Wikipedia, 2012):

Where:

$$
\begin{gathered}
\mathrm{Nu}=\frac{\mathrm{h}_{1} \mathrm{H}}{\mathrm{k}_{\mathrm{s}}} \\
N u=0.023 R_{e}^{0.8} P_{r}^{0.4} \\
R_{e}=\frac{\rho V_{m} D}{\mu} \\
P_{r}=\frac{C_{p \mu}}{k}
\end{gathered}
$$

$\mathrm{Nu}:$ Nusselt number

$\mathrm{H}$ : Channel depth, $\mathrm{m}$

$\mathrm{R}_{\mathrm{e}}$ : Reynolds number

$\mathrm{P}_{\mathrm{r}}$ : Prandtl number

$\rho:$ Bulk density of dough, $\mathrm{kg} / \mathrm{m}^{3}$

$\mathrm{V}_{\mathrm{m}}$ : mean fluid velocity, $\mathrm{m} / \mathrm{s}$

$\mu$ : Viscosity, pa.s

$\mathbf{C}_{\mathbf{p}}$ : Specific heat of soybean, $\mathrm{k} \mathrm{Cal} / \mathrm{kg}{ }^{\circ} \mathrm{C}$

Heat transfer coefficient of the barrel can be calculated by, (Wikipedia, 2012):

$$
h_{3}=\frac{k_{\text {in }}}{\text { thickness }}
$$

$\mathrm{k}_{\text {in }}$ : Thermal conductivety of insulation material, 
Table (3): the values of heat transfer coefficient of the barrel at different thickness of insulation:

\begin{tabular}{|l|l|l|l|l|l|l|}
\hline Thickness, m & 0.01 & 0.02 & 0.03 & 0.04 & 0.05 & 0.06 \\
\hline h3 & 3.8 & 1.9 & 1.266 & 0.95 & 0.76 & 0.63 \\
\hline
\end{tabular}

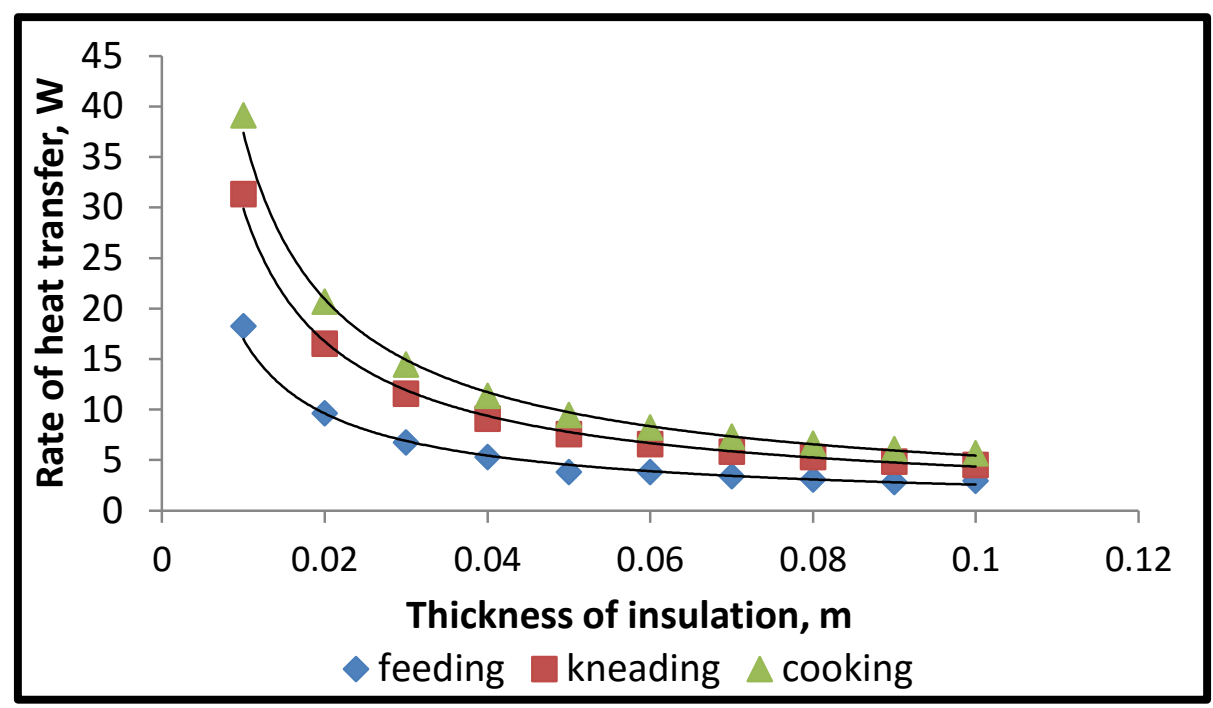

Fig .2. The rate of heat transfer from the insulated barrel to the surrounding air.

The applied diameter of insulation on the extruder's barrel was $0.1 \mathrm{~m}$ shown in Fig (3), and then evaluated the texturzed with different treatments.
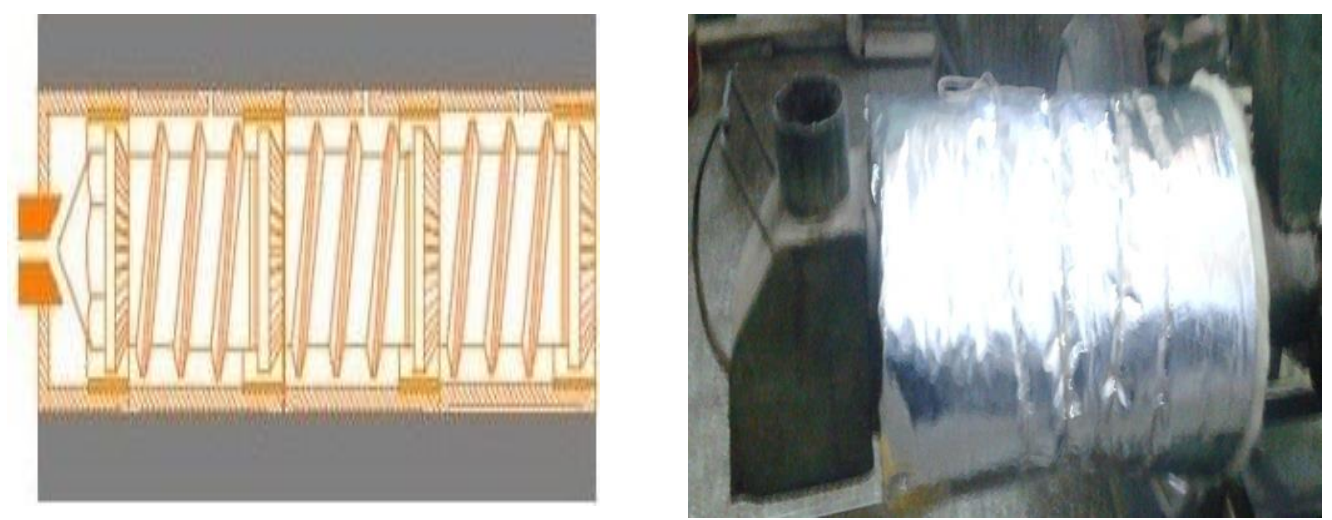

Fig .3. Applied the critcal radius of insulation on the extruder's barrel. 


\section{The modification of the die of the single screw extruder}

Nine dies were used in single screw extruder. Three different lengths of die were used with three different diameters. The best treatments of blends (soy bean - faba bean) and moisture content were applied by the different dies to choose the best one of dies. The shape of the die is shown in fig (4). The different dimensions of die are showing in table (4).

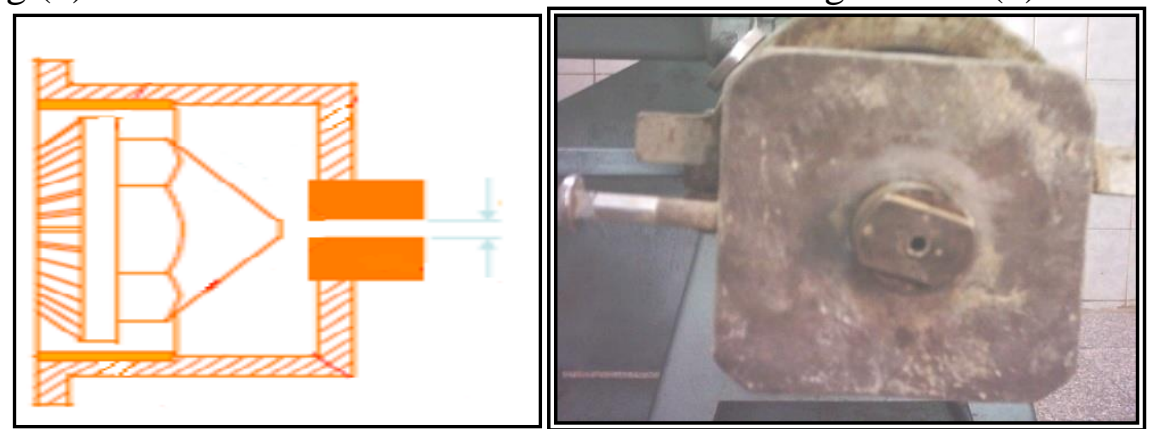

Fig. 4. The parts and a photo for the extruder's die area and the die.

Table (4): The specifications of the developed dies.

\begin{tabular}{|c|c|c|}
\hline \multirow{2}{*}{ Symbol } & \multicolumn{2}{|c|}{ Die } \\
\cline { 2 - 3 } & Length, mm & Diameter, $\mathrm{mm}$ \\
\hline 1 & 45 & 6 \\
\hline 2 & 45 & 8 \\
\hline 3 & 45 & 10 \\
\hline 4 & 65 & 6 \\
\hline 5 & 65 & 8 \\
\hline 6 & 65 & 10 \\
\hline 7 & 85 & 6 \\
\hline 8 & 85 & 8 \\
\hline 9 & 85 & 10 \\
\hline
\end{tabular}

\section{Calculation and Laboratory Measurements}

1. Moisture content, crude protein, fat, ash contents and total carbohydrates were determined according to the methods described in A.O.A.C (1980).

2.The $\mathrm{pH}$ of soybean flour was determined according $\mathrm{pH}$ meter according to the methods described in Ranganna (1977).

3.Water absorption capacity was measured by (A.A.C.C, 1995). 
4. Expansion ratio was determined by dividing mid point diameter of the extrudate grain by the diameter of die hole.

5.The bulk density was calculated from equation

$$
\mathbf{D}_{\mathbf{b}}=\mathbf{m} / \mathbf{V}
$$

where :

$\mathrm{D}_{\mathrm{b}}=$ The bulk density of soybean texturized, $\mathrm{g} / \mathrm{cm}^{3}$

$\mathrm{m}=$ The mass of soybean texturized, $\mathrm{g}$

$\mathrm{V}=$ The volume of soybean texturized, $\mathrm{cm}^{3}$

6.The soybean texturized hardness was determined using a digital force gauge.

7. The rotating speed of the used screw was determined using hand digital tachometer.

8. The temperature was determined using digital thermometers.

\section{RESULTS AND DISCUSSION \\ 1- Chemical Components of the different soy bean blends (Soybean and faba bean)}

The chemical components of the imported texturized soybean of: fat content, protein, total carbohydrates, ash, and moisture content are 0.5, $67.5,19.5,6.6$, and $5.9 \%$ respectively. Also, those for the locally produced ones are 7, 47.1, 29.8, 7.3, and 8.8\%, respectively. The chemical components of the modified texturized soybean (18\% moisture content $+\mathrm{CaCO}_{3} 1 \%$ ) were $1.5,48.89,35.31,8.2$, and $6 \%$ respectively (Morcos et al., 2007). The average values of the chemical components for the soybean blends with the blend ratios of bean 66.6:33.3, 50:50, 33.3:66.6, and 25:75 are shown in table (5). The value of protein content for the imported texturized soybean was $67.5 \%$ and that value of the locally produced texturized was $47.1 \%$, while the value of the local soybean texturized after the removed fat with solvent was $48.89 \%$. However, the average value of protein at those blend ratio of $(66.6 \%$ bean $+33.3 \%$ soybean, blend ratio of $(50 \%$ bean $+50 \%$ soybean $)$, blend ratio of $(33.3 \%$ bean $+66.6 \%$ soybean) and blend ratio ( $25 \%$ bean $+75 \%$ soybean) were $\approx 57.7,54.5,48.6$, and $46.8 \%$, respectively. So, increasing the percentage of the bean in the blends resulted in increasing the 
percentage of the protein in the locally produced and tested texturized soy bean blends.

\section{Table (5): Chemical Components of Soybean blends}

\begin{tabular}{lcccc}
\hline \multirow{2}{*}{$\begin{array}{l}\text { Chemical } \\
\text { Component }\end{array}$} & \multicolumn{4}{c}{$\begin{array}{c}\text { Percentage of } \\
\text { Blend }\end{array}$} \\
\cline { 2 - 5 } & $\begin{array}{c}\text { 66.6\% Bean }+ \\
\text { 33.3\% Soybean }\end{array}$ & $\begin{array}{c}50 \% \text { Bean }+ \\
\text { Soybean }\end{array}$ & $\begin{array}{c}33.3 \% \text { Bean }+ \\
\text { 66.6\% Soybean }\end{array}$ & 75\% Soybean \\
\hline Protein \% & 57.7 & 54.5 & 48.6 & 46.8 \\
Fat \% & 2.22 & 2.95 & 4.65 & 6.83 \\
Ash \% & 8.9 & 9.17 & 9.32 & 9.58 \\
Carbohydrates \% & 25.5 & 26.28 & 29.55 & 30.15 \\
\hline
\end{tabular}

The value of fat content for the imported texturized soybean was $0.5 \%$ and that value for the locally texturized was $7 \%$, while that value for the locally produced texturized soybean after the removal of fat with solvent was $1.5 \%$. However, the average value of fat at the blend ratio of $(66.6 \%$ bean $+33.3 \%$ soybean $)$, blend ratio of $(50 \%$ bean $+50 \%$ soybean $)$, blend ratio of $(33.3 \%$ bean $+66.6 \%$ soybean) and blend ratio of $(25 \%$ bean $+75 \%$ soybean) were $\approx 2.22,2.95,4.65$, and $6.83 \%$. So, increasing the percentage of the bean in the blends resulted in decreasing the percentage of fat in the locally produced and tested texturized soy bean blends. The value of ash content for the imported texturized soybean was $6.6 \%$ and that value for the locally texturized was $7.3 \%$, while that value for local texturized after the removal of fat with solvent was $8.2 \%$. However, the average value of ash content at the blend ratio of $(66.6 \%$ bean $+33.3 \%$ soybean) was $\approx 8.9 \%$, while the average value of ash content at the blend ratio (50\% bean $+50 \%$ soybean), blend ratio of (33.3\% bean $+66.6 \%$ soybean), and blends ratio of ( $25 \%$ bean $+75 \%$ soybean) were $\approx 8.9,9.17,9.32$, and $9.58 \%$ respectively. The value of the carbohydrates content for the imported texturized soybean was $19.5 \%$ and that for the locally texturized was $29.8 \%$, while that for local texturized after the removal of fat with solvent was $35.31 \%$. However, 
the average value of the carbohydrates content at the blend ratio of $(66.6 \%$ bean $+33.3 \%$ soybean), blend ratio of $(50 \%$ bean $+50 \%$ soybean), blend ratio of ( $33.3 \%$ bean $+66.6 \%$ soybean) and blend ratio of $(25 \%$ bean $+75 \%$ soybean $)$ were $\approx 25.5,26.28,29.55$, and $30.15 \%$, respectively.

\section{2- Physical Properties of the Modified Texturized (Soybean - faba Bean) blends Before and After applying Extruder's Heat Insulation.}

\section{The $\mathrm{pH}$ of the modified texturized soybean blends}

The average values of $\mathrm{pH}$ for the texturized blends of soybean for the different treatments with the blend ratio of bean 66.6:33, 50:50, 33.3:66.6, and 25:75 are shown in Table (5). The value of $\mathrm{pH}$ for the imported texturized soybean was 6.7 and that for the local texturized was 8.7. From table (6), the average value of $\mathrm{pH}$ at the un-insulated treatments A, B, C, D, E, F, G, H, I, J, K, L, M, N, O, and P were ranging between 6.8 and 6.9 , while those of the insulated treatments were ranging between 6.6 and 6.8 .

\section{The bulk density $\left(\rho_{b}\right)$ of the modified texturized soybean blends}

The value of bulk density for the imported texturized soybean blends was $321 \mathrm{~g} / 1$ and those value for local texturized was $485 \mathrm{~g} / \mathrm{l}$. However, the average value of bulk density at the non insulated treatments $\mathrm{A}, \mathrm{B}, \mathrm{C}, \mathrm{D}$, E, F, G, H, I, J, K, L, M, N, O, and P were ranged 210.5 to $381.5 \mathrm{~g} / \mathrm{l}$. While the average value of bulk density at the insulated were ranged 220.5 to $360.5 \mathrm{~g} / \mathrm{l}$.

These results indicate that the aggregates of the treatments at the blend ratio ( $50 \%$ bean $+50 \%$ soybean) could be more stable due to its expect higher hardness, and the interspaces between them are not filled with the powder of the texturized flour or the small aggregates, which could be produced by the collapse of the produced grains. 
Table (6): The physical properties of soybean texturized.

\begin{tabular}{|c|c|c|c|c|c|c|c|c|c|c|}
\hline \multirow[t]{2}{*}{ symbol } & \multicolumn{2}{|c|}{ pH } & \multicolumn{2}{|c|}{ Bulk density, g/l } & \multicolumn{2}{|c|}{ Hardness, $\mathbf{N}$} & \multicolumn{2}{|c|}{$\begin{array}{c}\text { Water } \\
\text { absorption } \\
\text { capacity, \% }\end{array}$} & \multicolumn{2}{|c|}{ Expansion ratio } \\
\hline & Ins. & Non. & Ins. & Non. & Ins. & Non. & Ins. & Non. & Ins. & Non. \\
\hline $\mathbf{A}$ & 6.60 & 6.8 & 220.50 & 210.50 & 18.10 & 16.50 & 399 & 396 & 4.81 & 4.71 \\
\hline B & 6.70 & 6.9 & 236.80 & 214.36 & 18.90 & 17.20 & 400 & 399 & 4.75 & 4.66 \\
\hline $\mathbf{C}$ & 6.60 & 7.01 & 235.36 & 220.69 & 19.50 & 17.90 & 407 & 402 & 4.71 & 4.61 \\
\hline D & 6.60 & 6.8 & 251.69 & 230.50 & 20.10 & 18.10 & 410 & 408 & 4.67 & 4.58 \\
\hline $\mathbf{E}$ & 6.68 & 7.02 & 329.13 & 326.20 & 20.45 & 18.36 & 420 & 410 & 5.05 & 4.95 \\
\hline $\mathbf{F}$ & 6.70 & 6.94 & 334.10 & 330.50 & 25.62 & 22.30 & 418 & 408 & 4.95 & 4.85 \\
\hline $\mathbf{G}$ & 6.50 & 6.97 & 338.90 & 333.20 & 27.69 & 25.00 & 415 & 405 & 4.77 & 4.69 \\
\hline $\mathbf{H}$ & 6.50 & 6.81 & 342.50 & 338.40 & 28.74 & 26.00 & 410 & 400 & 4.61 & 4.66 \\
\hline I & 6.70 & 6.72 & 332.10 & 340.82 & 25.83 & 22.00 & 405 & 400 & 4.95 & 4.45 \\
\hline $\mathbf{J}$ & 6.79 & 6.83 & 337.10 & 344.60 & 28.96 & 24.30 & 400 & 398 & 4.64 & 4.23 \\
\hline $\mathbf{K}$ & 6.83 & 6.94 & 339.70 & 348.71 & 28.53 & 26.40 & 397 & 381 & 4.3 & 4.19 \\
\hline $\mathbf{L}$ & 6.70 & 6.89 & 341.07 & 354.27 & 30.53 & 28.10 & 393 & 378 & 4.23 & 4.11 \\
\hline M & 6.8 & 6.86 & 348.13 & 358.23 & 29.43 & 28.80 & 387 & 380 & 3.70 & 3.76 \\
\hline $\mathbf{N}$ & 6.82 & 6.96 & 350.60 & 368.20 & 32.30 & 30.80 & 380 & 377 & 3.34 & 3.71 \\
\hline $\mathbf{O}$ & 6.75 & 6.85 & 355.06 & 375.60 & 39.79 & 32.60 & 372 & 371 & 3.30 & 3.67 \\
\hline $\mathbf{P}$ & 6.80 & 6.86 & 360.50 & 381.50 & 40.75 & 37.80 & 370 & 365 & 3.26 & 3.58 \\
\hline
\end{tabular}

Table (7): Mathematical equations and $\mathbf{R}^{2}$ expressing the relationship between moisture content and bulk density for the different of soybean blends before and after applying extruder heat insulation.

\begin{tabular}{c|c|c}
\hline Blend ratio & The equation (before extruder heat insulation) & $\mathbf{R}^{\mathbf{2}}$ \\
\hline $66.6 \%$ Bean & $\mathrm{y}=0.0842 \mathrm{x}^{2}-2.3149 \mathrm{x}+226.45$ & 0.9979 \\
$50.0 \%$ Bean & $\mathrm{y}=-0.4279 \mathrm{x}^{2}+26.372 \mathrm{x}-65.39$ & 0.9854 \\
$33.3 \%$ Bean & $\mathrm{y}=-0.5853 \mathrm{x}^{2}+30.847 \mathrm{x}-47.431$ & 0.9474 \\
$25.0 \%$ Bean & $\mathrm{y}=0.8393 \mathrm{x}^{2}-30.945 \mathrm{x}+638.01$ & 0.9503 \\
\hline & The equation $($ after extruder heat insulation) & \\
$66.6 \%$ Bean & $\mathrm{y}=0.0654 \mathrm{x}^{2}+5.1665 \mathrm{x}+247.23$ & 0.8446 \\
$50.0 \%$ Bean & $\mathrm{y}=-0.0363 \mathrm{x}^{2}+2.2237 \mathrm{x}+306.97$ & 0.9985 \\
$33.3 \%$ Bean & $\mathrm{y}=-0.3672 \mathrm{x}^{2}+22.342 \mathrm{x}+4.5467$ & 0.9863 \\
$25.0 \%$ Bean & $\mathrm{y}=0.0003 \mathrm{x}^{2}+1.8291 \mathrm{x}+194.77$ & 0.8707 \\
\hline
\end{tabular}

$\mathrm{x}=$ moisture content $\%, \mathrm{y}=$ bulk density $\mathrm{g} / \mathrm{l}$ 


\section{The hardness $\left(\mathrm{H}_{\mathrm{t}}\right)$ of the modified texturized soybean blends}

The average values of the hardness $\left(\mathrm{H}_{\mathrm{t}}\right)$ for the modified texturized (bean + soybean) before and after extruder heat insulation are shown in Table (6)._The value of hardness for the imported texturized soybean was 18.7 $\mathrm{N}$ and those value for local texturized was $11.6 \mathrm{~N}$. However, the average value of hardness at the non insulated treatments $\mathrm{A}, \mathrm{B}, \mathrm{C}, \mathrm{D}, \mathrm{E}, \mathrm{F}, \mathrm{G}, \mathrm{H}$, $\mathrm{I}, \mathrm{J}, \mathrm{K}, \mathrm{L}, \mathrm{M}, \mathrm{N}, \mathrm{O}$, and $\mathrm{P}$ were ranged from 16.5 to $37.8 \mathrm{~N}$. While the average value of hardness at the insulated treatments were ranged from 18.1 to $40.7 \mathrm{~N}$. These results indicate that the aggregates of the treatments at the blend ratio $(66.6 \%$ bean $+33.3 \%$ soybean $)$ and $(50 \%$ bean $+50 \%$ soybean) are expected to be more stable due to its higher hardness, and the percentages of powder of the soybean texturized are lower than those of the other blends. Figs, $(5 \& 6)$ show the relation of the hardness and moisture content of the modified texturized (soybean bean) for the different treatments before and after extruder heat insulation. The second degree polynomial equation obtained by effect of feed moisture content versus hardness at different ranges of blend ratio before and after insulated are shown in Table (8).

Table (8): Mathematical equations and $R^{2}$ expressing the relationship between moisture content and hardness for the different of soybean blends before and after applying extruder heat insulation.

\begin{tabular}{l|c|c}
\hline Blend ratio & The equation (before extruder heat insulation) & $\mathbf{R}^{2}$ \\
\hline $66.6 \%$ Bean & $\mathrm{y}=-0.005 \mathrm{x}^{2}+0.335 \mathrm{x}+12.575$ & 0.9921 \\
$50.0 \%$ Bean & $\mathrm{y}=-0.0294 \mathrm{x}^{2}+1.8354 \mathrm{x}-2.579$ & 0.9997 \\
$33.3 \%$ Bean & $\mathrm{y}=-0.006 \mathrm{x}^{2}+0.678 \mathrm{x}+13.17$ & 0.9999 \\
$25.0 \%$ Bean & $\mathrm{y}=0.032 \mathrm{x}^{2}-0.864 \mathrm{x}+34.74$ & 0.9855 \\
\hline & The equation $($ after extruder heat insulation) & \\
& $\mathrm{y}=-0.002 \mathrm{x}^{2}+0.222 \mathrm{x}+15.23$ & \\
$66.6 \%$ Bean & $\mathrm{y}=-0.0412 \mathrm{x}^{2}+2.3928 \mathrm{x}-6.068$ & 0.9991 \\
$50.0 \%$ Bean & $\mathrm{y}=-0.0113 \mathrm{x}^{2}+0.7819 \mathrm{x}+16.944$ & 0.9947 \\
$33.3 \%$ Bean & $\mathrm{y}=-0.0191 \mathrm{x}^{2}+1.6885 \mathrm{x}+7.8425$ & 0.8434 \\
$25.0 \%$ Bean & & 0.9332 \\
\hline
\end{tabular}

$\mathrm{x}=$ moisture content $\%, \mathrm{y}=$ hardness 
The water absorption capacity (WAC) of the modified texturized soybean blends

The results of the water absorption capacity (WAC) of the modified soybean texturized for all treatments before and after extruder heat insulation are shown in Table (6). The value of WAC for the imported texturized soybean was $400.7 \%$ and those value for local texturized was $265 \%$. However, the average value of $\mathrm{WAC}$ at the non insulated treatments A, B, C, D, E, F, G, H, I, J, K, L, M, N, O, and P were ranged from 396 to $410 \%$. While the average value of WAC at the insulated treatments were ranged from 399 to $420 \%$. These results show that the presence of fat affected water absorption capacity. From this point of view, the imported texturized soybean had the highest water absorption capacity, since its fat content is only $0.5 \%$, beside its high hardness value which causes its aggregates to be stable and prevents its collapse. Figs, ( 7 $\& 8)$ show the relation of the WAC and moisture content of the modified texturized (soybean - bean) for the different treatments before and after extruder heat insulation. The second degree polynomial equation obtained by effect of feed moisture content versus WAC at different ranges of blend ratio before and after insulated are shown in Table (9).

Table (9): Mathematical equations and $R^{2}$ expressing the relationship between moisture content and WAC for the different of soybean blends before and after applying extruder heat insulation.

\begin{tabular}{c|c|c}
\hline Blend ratio & The equation (before extruder heat insulation) & $\mathbf{R}^{\mathbf{2}}$ \\
\hline $66.6 \%$ Bean & $\mathrm{y}=-0.0253 \mathrm{x}^{2}+0.6652 \mathrm{x}+412.15$ & 0.9984 \\
$50.0 \%$ Bean & $\mathrm{y}=0.1176 \mathrm{x}^{2}-6.9779 \mathrm{x}+486.9$ & 0.9927 \\
$33.3 \%$ Bean & $\mathrm{y}=-0.0458 \mathrm{x}^{2}+0.6171 \mathrm{x}+399.1$ & 0.8338 \\
$25.0 \%$ Bean & $\mathrm{y}=-0.03 \mathrm{x}^{2}+0.33 \mathrm{x}+381.95$ & 0.9966 \\
\hline & The equation $($ after extruder heat insulation) & \\
& $\mathrm{y}=-0.0059 \mathrm{x}^{2}+0.4898 \mathrm{x}+388.48$ & 0.9988 \\
$66.6 \%$ Bean & $\mathrm{y}=-0.0409 \mathrm{x}^{2}+1.658 \mathrm{x}+387.49$ & 0.8069 \\
$50.0 \%$ Bean & $\mathrm{y}=0.0061 \mathrm{x}^{2}-1.061 \mathrm{x}+419.45$ & 0.9978 \\
$33.3 \%$ Bean & $\mathrm{y}=0.0002 \mathrm{x}^{2}-2.0354 \mathrm{x}+428.87$ & 0.8615 \\
$25.0 \%$ Bean & &
\end{tabular}

$\mathrm{x}=$ moisture content $\%, \mathrm{y}=\mathrm{WAC} \%$

The expansion ratio of the modified texturized soybean blends

The results of the expansion ratio of the modified soybean texturized for all treatments before and after extruder heat insulation are shown in 
Table (6). The average value of expansion ratio at the non insulated treatments A, B, C, D, E, F, G, H, I, J, K, L, M, N, O, and P were ranged from 3.58 to 4.95 While the average value of WAC at the insulated treatments were ranged from 3.26 to 5.05. Figs ( $9 \& 10$ ) show the relation of the expansion ratio and moisture content of the modified texturized (soybean - bean) for the different treatments before and after extruder heat insulation. The second degree polynomial equation obtained by effect of feed moisture content versus expansion ratio at different ranges of blend ratio before and after insulated are shown in Table (10).

Table (10): Mathematical equations and $R^{2}$ expressing the relationship between moisture content and expansion ratio for the different of soybean blends before and after applying extruder heat insulation.

\begin{tabular}{c|c|c}
\hline Blend ratio & The equation (before extruder heat insulation) & $\mathbf{R}^{\mathbf{2}}$ \\
\hline $66.6 \%$ Bean & $\mathrm{y}=0.0002 \mathrm{x}^{2}-0.0178 \mathrm{x}+4.933$ & 0.998 \\
$50.0 \%$ Bean & $\mathrm{y}=0.0058 \mathrm{x}^{2}-0.3159 \mathrm{x}+8.3736$ & 0.9884 \\
$33.3 \%$ Bean & $\mathrm{y}=0.0014 \mathrm{x}^{2}-0.0842 \mathrm{x}+5.387$ & 0.9619 \\
$25.0 \%$ Bean & $\mathrm{y}=-0.0004 \mathrm{x}^{2}+0.0064 \mathrm{x}+3.751$ & 0.9897 \\
\hline & The equation $($ after extruder heat insulation) & \\
& $\mathrm{y}=-0.0007 \mathrm{x}^{2}+0.0367 \mathrm{x}+4.4222$ & 0.9994 \\
$56.6 \%$ Bean & $\mathrm{y}=-0.0006 \mathrm{x}^{2}-0.003 \mathrm{x}+5.235$ & 0.9956 \\
$50.0 \%$ Bean & $\mathrm{y}=0.0024 \mathrm{x}^{2}-0.158 \mathrm{x}+6.795$ & 0.9864 \\
$23.3 \%$ Bean & $\mathrm{y}=0.001 \mathrm{x}^{2}-0.147 \mathrm{x}+6.5724$ & 0.9176 \\
\hline
\end{tabular}

$\mathrm{x}=$ moisture content $\%, \mathrm{y}=$ expansion ratio

3- Physical properties of the modified texturized (Soybean - faba Bean) blends with different dies after applying extruder's heat insulation.

After applied the blends of (soybean - faba bean) at different ratio (33.3:66.6, 50:50, 66.6:33.3, and 75:25) and different moisture content $(15,20,25$, and 30\%). These treatments applied in the single screw extruder with thermal insulation and without thermal insulation at three zones of barrel (feeding, kneading, and cooking). It was found that the best treatments of blends were E (50\% soy bean : $50 \%$ faba bean + 
moisture content $20 \%$ ) and $\mathrm{F}(50 \%$ soy bean : $50 \%$ faba bean blends + $25 \%$ ) were used with different dies in Table (4). The values of physical properties for texturized are shown in Table (11).

The physical properties of the imported texturized soybean were 6.7, $321 \mathrm{~g} / \mathrm{l}, 18.7 \mathrm{~N}, 400.7 \%$ and the values of the locally texturized soy bean were $8.7,485 \mathrm{~g} / 1,11.6 \mathrm{~N}, 265 \%$ for $\mathrm{pH}$, bulk density, hardness, and water absorption capacity, respectively.

From Tables $(5,11)$ it was observed that the treatment F7 (50\% soy bean : $50 \%$ faba bean ) $+25 \%$ moisture content with die diameter $6 \mathrm{~mm}$ and $85 \mathrm{~mm}$ length was the best.

Table (11): The Physical properties of modified texturized (Soybean - faba Bean) blends with different dies after applying extruder's Heat Insulation.

\begin{tabular}{|c|c|c|c|c|c|}
\hline Symbol & $\mathrm{pH}$ & $\begin{array}{c}\text { Bulk } \\
\text { density, g/l }\end{array}$ & $\begin{array}{c}\text { Hardness, } \\
\mathrm{N}\end{array}$ & $\begin{array}{c}\text { Water } \\
\text { Absorption } \\
\text { Capacity, } \%\end{array}$ & $\begin{array}{c}\text { Expansion } \\
\text { ratio }\end{array}$ \\
\hline $\mathbf{1}$ & $\mathbf{2}$ & $\mathbf{3}$ & $\mathbf{4}$ & $\mathbf{5}$ & $\mathbf{6}$ \\
\hline E1 & 6.66 & 332.6 & 11.4 & 380 & 4.13 \\
\hline F1 & 6.68 & 346.0 & 10.3 & 379 & 4.81 \\
\hline E2 & 6.66 & 355.1 & 12.5 & 377 & 4.23 \\
\hline F2 & 6.71 & 360.5 & 13.2 & 381 & 4.61 \\
\hline E3 & 6.80 & 432.6 & 14.2 & 369 & 4.55 \\
\hline F3 & 6.45 & 376.0 & 14.9 & 366 & 4.65 \\
\hline E4 & 6.64 & 332.13 & 20.45 & 410 & 4.13 \\
\hline F4 & 6.63 & 336.9 & 20.91 & 405 & 4.38 \\
\hline E5 & 6.57 & 342.5 & 25.01 & 420 & 4.22 \\
\hline F5 & 6.56 & 339.7 & 26.0 & 418 & 4.61 \\
\hline E6 & 6.59 & 408.67 & 27.2 & 415 & 4.51 \\
\hline F6 & 6.54 & 409.3 & 26.3 & 413 & 4.45 \\
\hline E7 & 6.66 & 305.6 & 13.6 & 422 & 5.12 \\
\hline F7 & 6.71 & 316.1 & 15.8 & 429 & 5.62 \\
\hline E8 & 6.53 & 330.0 & 15.2 & 419 & 4.95 \\
\hline F8 & 6.64 & 328.7 & 15.4 & 419 & 4.81 \\
\hline E9 & 6.59 & 361.7 & 19.9 & 417 & 4.83 \\
\hline F9 & 6.58 & 366.9 & 16.1 & 415 & 4.87 \\
\hline
\end{tabular}




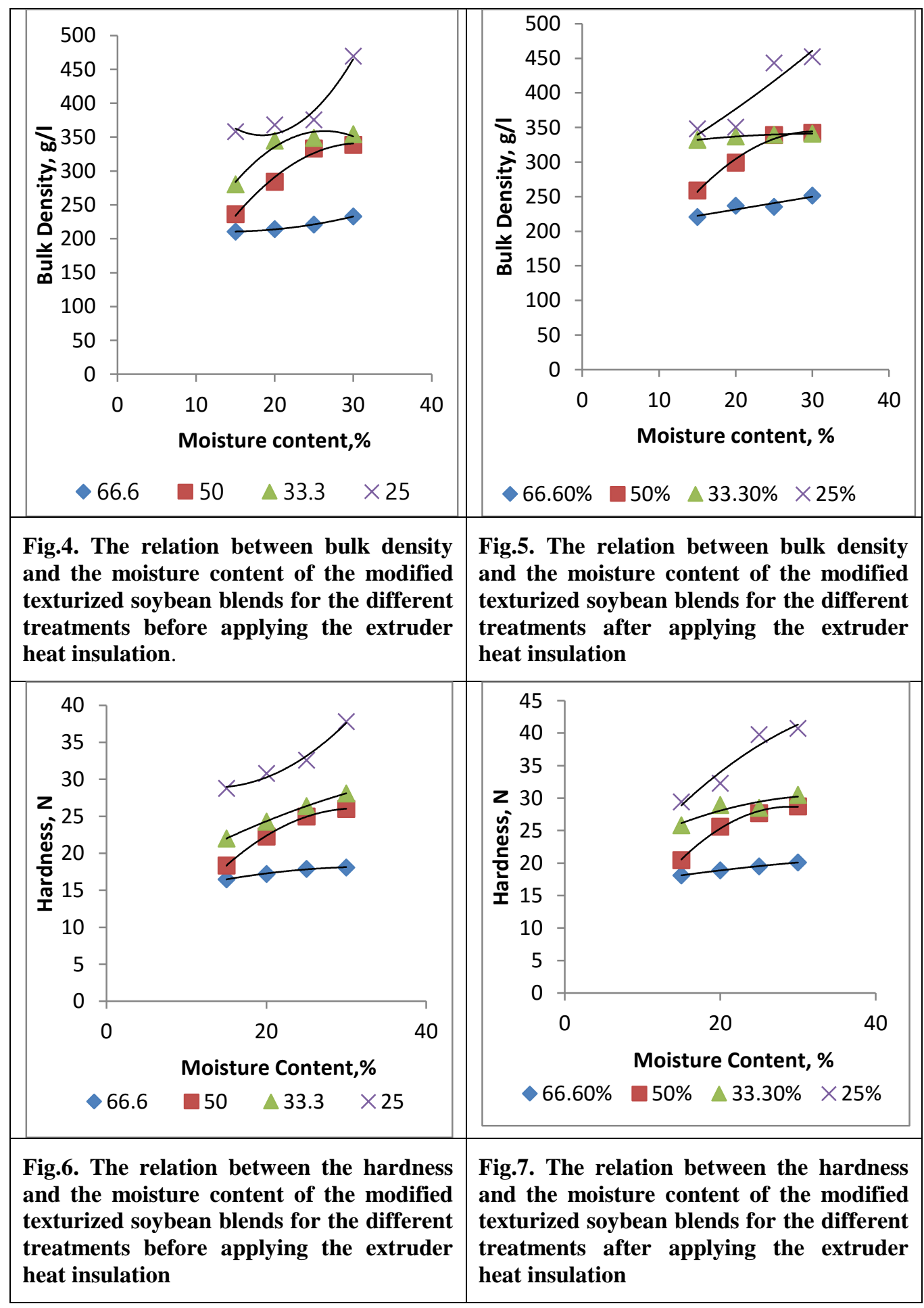



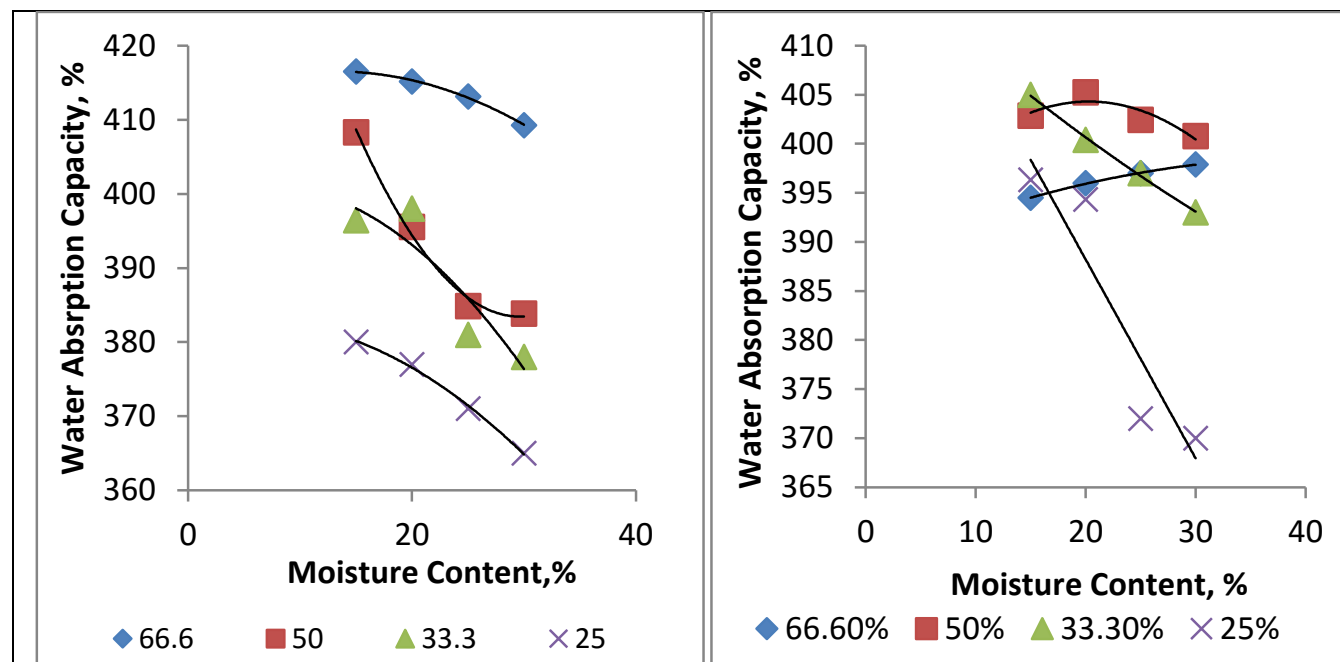

Fig.8. The relation between the WAC and the moisture content of the modified texturized soybean blends for the different treatments before applying the extruder heat insulation.

Fig.9. The relation between the WAC and the moisture content of the modified texturized soybean blends for the different treatments after applying the extruder heat insulation

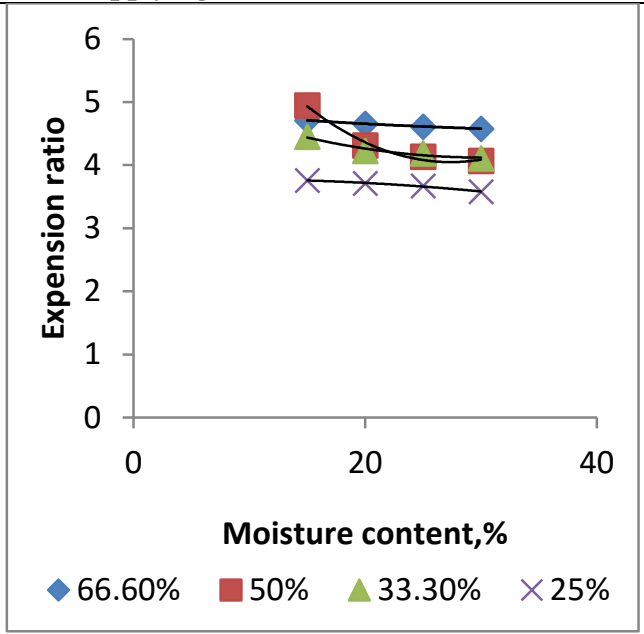

Fig.10. The relation between the Expansion ratio and the moisture content of the modified texturized soybean blends for the different treatments before applying the extruder heat insulation.

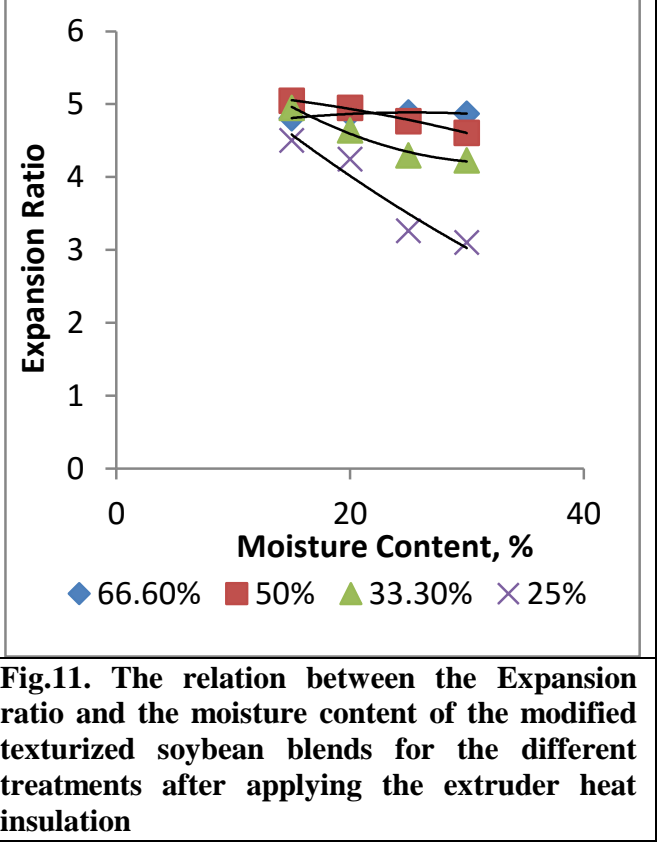

\section{CONCLUSION}

Soybean came the first of the natural alternates for meat, because it is high in protein "containing 38\%" by weight. The locally produced texturized soybean is containing $7 \%$ fat but the imported one is containing $0.5 \%$ fat. To reduce the effect of fat, a suggestion of the addition of some legumes (Faba bean) which contain low amount of fat was proposed to make soy 
flour blends having low fat content. It was found that percentage of 50:50 (soybean: bean) is the best. To raise the temperature inside the barrel used fiber glass insulation and found that $0.10 \mathrm{~m}$ thickness was the best.

\section{REFERENCES}

A.O.A.C. 1980. Official methods of analysis, $12^{\text {th }}$ ed. Association of official analytical chemists. Washington, D.C .

A.A.C.C. 1995 . ( Approval methods ) of the American Association of Cereal Chemists . Published by the American Association of cereal chemists. Inc. St. Paul, Minnesota, U.S.A .

Chakraborty, P. and S. Banerjee. 2009. Optimization of extrusion process for production of expanded product from green gram and rice by response surface methodology. Journal of Scientific \& Industrial Research. 68, 140-148.

Cengel Y. A. and A. J. Ghajar. 2011. Heat and Mass Transfer : Fundamentals and Applications. Fourth Edition. ISBN: 0073398128.

Kumar S. S. 2012. Selection of Insulation Material. P-248, MMDA Colony, Arambakkam, Chennai _600 106_.

Heldman D. R. and D. B. Lund. 2007. Hand book of food engineering. Second edition. CRC Press, London, Boca Raton, New York. Pp.1023.

Larralde, J. and J.A. Martinez. 1991. Nutritional value of faba bean: effects on nutrient utilization, protein turnover and immunity. CIHEAM - Options Mediterraneennes. Vol: 10, 111-117.

Liang, Y., S. R. Hosahalli and Joyce Boye. 2009. Twin-screw extrusion of corn flour and soy protein isolate (SPI) blends: A response surface analysis. Food Bioprocess Technol.

Linko , P. ,Y. Y. Linko and J. Olkku . 1983. Extrusion cooking and bioconversions . J.Food Eng. 2:243 .

Lienhard J. H. 2008. Heat Transfer Text Book. Third edition. Published by Phlogiston Press, Cambridge, U.S.A.

Morcos, M.A., M.I. Ghonimy, H.K. El-Manawaty, and M.M.H. Zakzouk. 2007. Improving the properties of the locally produced texturized from soybean. Misr Journal of Agricultural Engineering. Vol (24), No. 3. 
Ranganna , S . 1977 . Manual of Analysis Fruit and Vegetable Products . Tata McGraw-Hill Publishing Company Limited . New Delhi .

U.S.B. 2004 .United Soy bean Borad . Soy and health .

Wikipedia. 2012. Heat transfer coefficient.

http://en.wikipedia.org/wiki/convictive_heat transfer

\section{الملخص العربي \\ تحسين خواص اضافات اللحوم المصنعة من خلائط مختلفة من فول الصويا بواسطة الصنائ

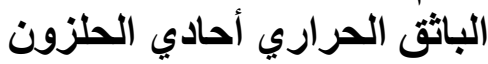

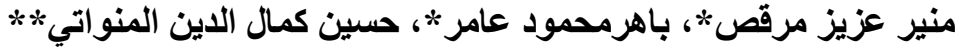

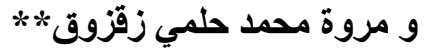

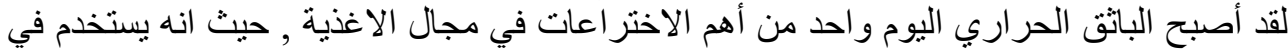

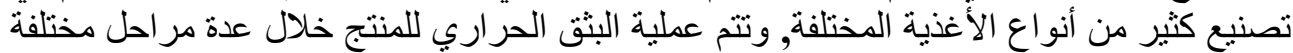

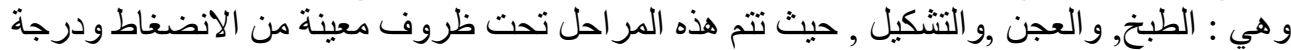

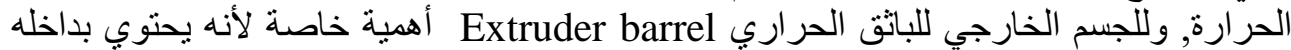

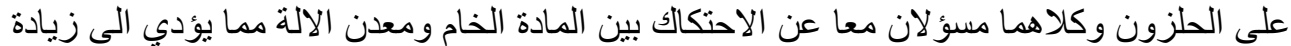

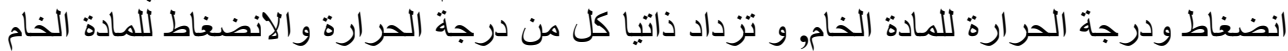

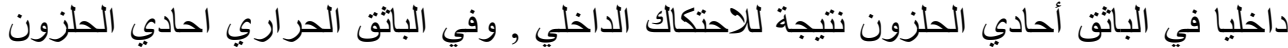

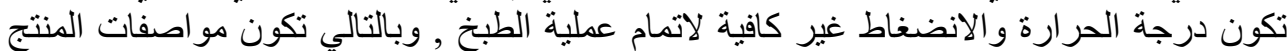

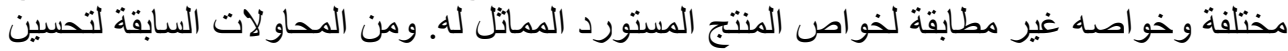

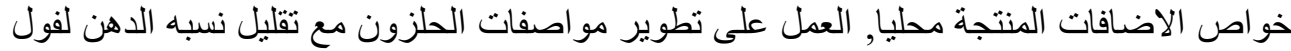

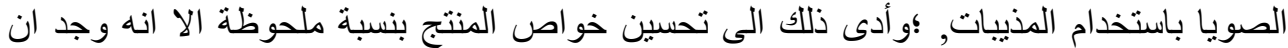

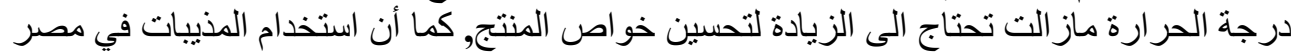

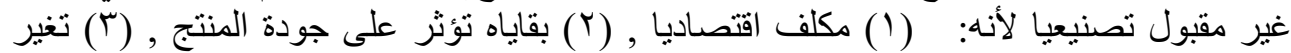

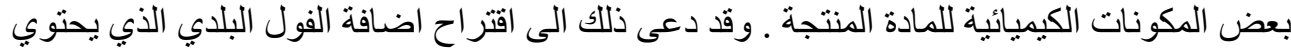

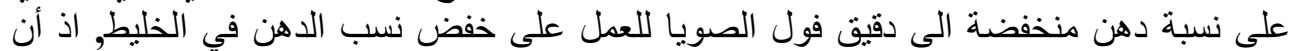

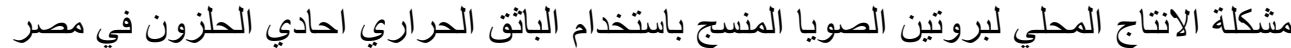

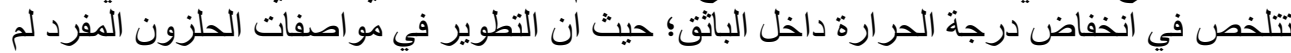

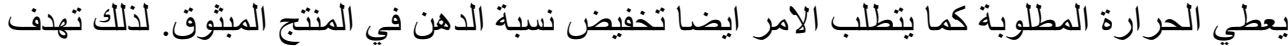

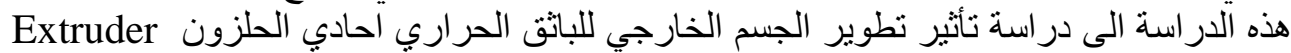

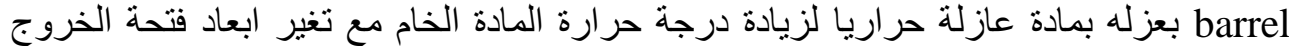

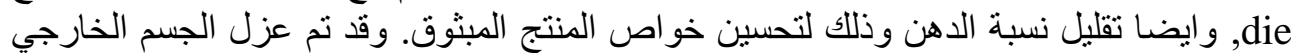

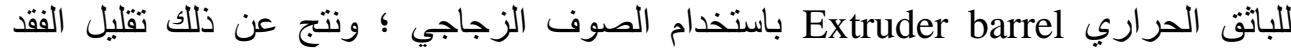

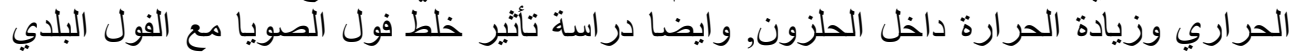

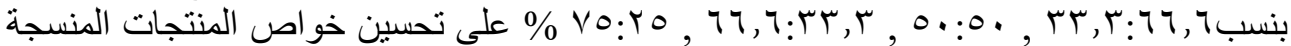

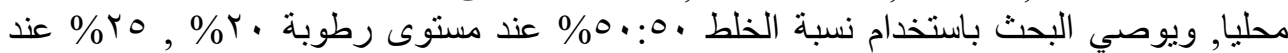

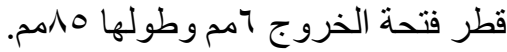

* قسم الهندسة الزراعية ـ كلية الزراعة ـ جامعة القاهرة.

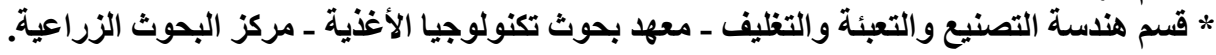

